\begin{tabular}{|l|l|l||}
\hline \multicolumn{2}{|c|}{ PublisherInfo } \\
\hline \hline PublisherName & $:$ & BioMed Central \\
\hline \hline PublisherLocation & $:$ & London \\
\hline \hline PublisherImprintName & $:$ & BioMed Central \\
\hline \hline
\end{tabular}

\title{
Cartilage defects in Sox9 heterozygotes
}

\begin{tabular}{|l|l|l||}
\hline \multicolumn{2}{|c|}{ ArticleInfo } \\
\hline \hline ArticleID & $:$ & 82 \\
\hline \hline ArticleDOI & $:$ & $10.1186 /$ ar-2001-68281 \\
\hline \hline ArticleCitationID & $:$ & 68281 \\
\hline \hline ArticleSequenceNumber & $:$ & 39 \\
\hline \hline ArticleCategory & $:$ & Paper Report \\
\hline ArticleFirstPage & $:$ & 1 \\
\hline \hline ArticleLastPage & $:$ & 3 \\
\hline \hline & & RegistrationDate : 2001-7-27 \\
ArticleHistory & $:$ & Received \\
\hline \hline ArticleCopyright & $:$ & Biomed Central Ltd2001-7-27 \\
\hline \hline ArticleGrants & $:$ & \\
\hline \hline ArticleContext & $:$ & 130753311 \\
\hline \hline
\end{tabular}


Aff1 NIAMS, National Institutes of Health, Bethesda, MD, USA

\section{Keywords}

Campomelic dysplasia, cartilage, chondrogenesis, knockout mouse, mineralization, transcription factors

\section{Context}

Sox9 is a high mobility group (HMG)-box DNA-binding transcription factor that is essential for chondrogenesis. During embryonic development, Sox9 is expressed at high levels in all chondroprogenitor cells. Sox9 directly regulates the expression of cartilage-specific genes such as types II and XI collagens. Mutations in the human SOX9 gene result in haploinsufficiency and the skeletal malformation syndrome campomelic dysplasia (CD). CD patients are characterized by a number of skeletal malformations typifies by short limb dwarfism and bowing of the tibiae and femora, craniofacial dysmorphogenesis including cleft palate and micrognathia, and XY sex reversal. Previously, this group has generated embryonic stem (ES) cells bearing targeted disruption of Sox9 (see Additional information [1]) and discovered that no cartilage developed in teratomas derived from Sox $9^{-/-}$ES cells. This study generated Sox9 heterozygous mutant mice with reduced Sox9 expression level, which produce a phenotype similar to that of the CD scenario.

\section{Significant findings}

The mice were generated with significantly reduced Sox 9 transcript and protein levels in newborn chondrocytes. Reduced levels of Sox 9 and type II collagen were detected as early as embryonic day 10.5 (E10.5). Mutant animals exhibited perinatal lethality, cleft secondary palate and skeletal defects of all bones derived from endochondral ossification, notably hypoplasia and bending. These defects were attributed to delay or defective formation of cartilage primordia. These skeletal abnormalities are similar to those found in CD patients. Skeletal patterning was not affected. Mutant animals also showed premature mineralization of skeletal elements, including that of the craniofacial region and vertebral column. The overall organization upon analyses of the growth plate in the heterozygote was comparable to wild type, and the resting and proliferating zones were similar. However, the hypertrophic zone in the heterozygote was thicker as demonstrated by an expanded region of type $\mathrm{X}$ collagen expression. The authors concluded that Sox9 dosage is critical for mesenchymal condensation of cartilage primordia and the maintenance of chondrocyte in prehypertrophy. 


\section{Comments}

Numerous in vitro studies have discovered that Sox9 is necessary and critical for the specification of the chondrocyte lineage and the early formation of cartilage. This investigation is unique in three ways: it supports in vivo functions of Sox9 during chondrogenesis, it provides an animal model that phenocopies in part the human CD syndrome, and it identifies the additional function of Sox9 in the growth plate. Interestingly, within the growth plate, Sox 9 function may be regulated by parathyroid hormone related peptide. This regulation may occur post-translationally by phosphorylation of Sox 9 .

\section{Methods}

Targeted disruption of Sox9, homologous recombination, mutant ES cells, germline transmission, Southern analysis or PCR; alcian blue, alizarin red, and ?-galactosidase staining; immunohistochemistry; in situ hybridization; northern and western analyses

\section{Additional information}

1. Bi W, Deng JM, Zhang Z, Behringer RR, de Crombrugghe B: Sox9 is required for cartilage formation. Nat Genet 1999, 22: 85-89 (PubMed abstract).

Huang W, Chung UI, Kronenberg HM, de Crombrugghe B: The chondrogenic transcription factor Sox9 is a target of signaling by the parathyroid hormone-related peptide in the growth plate of endochondral bones. Proc Natl Acad Sci USA 2001, 98: 160-165 (PubMed abstract).

Online Mendelian Inheritance in Man, entry 114290 Campomelic Dysplasia

\section{References}

1. Bi W, Huang W, Whitworth DJ, Deng JM, Zhang Z, Behringer RR, de Crombrugghe B: Haploinsufficiency of Sox 9 results in defective cartilage primordia and premature skeletal mineralization. Proc Natl Acad Sci USA . 2001, 98: 6698-6703.

This PDF file was created after publication. 